Revue belge de géographie

3-4 | 2008

Formatting Europe - Mapping a Continent

\title{
Bringing the map to life: European satirical maps
}

\section{5-1945}

Cartes satiriques de l'Europe 1845-1945 ou comment donner de la vie aux cartes

\section{Roderick M. Barron}

\section{(2) OpenEdition}

1 Journals

\section{Electronic version}

URL: http://journals.openedition.org/belgeo/11935

DOI: $10.4000 /$ belgeo. 11935

ISSN: 2294-9135

Publisher:

National Committee of Geography of Belgium, Société Royale Belge de Géographie

\section{Printed version}

Date of publication: 31 December 2008

Number of pages: 445-464

ISSN: 1377-2368

\section{Electronic reference}

Roderick M. Barron, "Bringing the map to life: European satirical maps 1845-1945 ", Belgeo [Online],

3-4 | 2008, Online since 06 August 2014, connection on 05 February 2021. URL: http://

journals.openedition.org/belgeo/11935; DOl: https://doi.org/10.4000/belgeo.11935

This text was automatically generated on 5 February 2021.

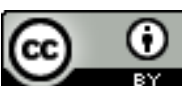

Belgeo est mis à disposition selon les termes de la licence Creative Commons Attribution 4.0 International. 


\title{
Bringing the map to life: European satirical maps 1845-1945
}

Cartes satiriques de l'Europe 1845-1945 ou comment donner de la vie aux cartes

\author{
Roderick M. Barron
}

\section{Introduction}

1 The $17^{\text {th }}$ Century Dutch carte- $a$-figures presented an almost iconographic image in which the centre of the engraved geographical map sheet was supplemented and embellished by border representations of peoples and places. The ostensible aim of the cartographer was to try to provide the viewer with an encapsulation of the fundamental "essence" of the country or region displayed. In the $16^{\text {th }} \& 17^{\text {th }}$ Century, Europe was the dominant Continental Power, a symbol of civilisation and culture, heiress of the great classical Empires of Greece and Rome. So she appeared in visual form on the title pages of the Great Atlases of the period, such as Abraham Ortelius' Theatrum Orbis Terrarum [Antwerp, 1570-1612].

2 This same European Queen, first appeared in map form in 1537 in a design by Johannes Putsch or Bucius, which was widely popularised in the subsequent derivatives of Heinrich Bünting [1581] and Matthias Quad [1587] and in editions of Sebastian Munster's Cosmographia from 1588 onwards (Figure 1). As well as offering a recognisable metaphor for Europe as the Queen of Culture and Civilisation, the map perhaps also provides a parallel political metaphor for contemporary $16^{\text {th }}$ Century Europe. Here is Europe the Holy Roman Empress or the Austro-Spanish Queen, representative of the extensive and all-powerful territorial dominions of the Hapsburg Empire of Charles V and Phillip II, her head in Spain and her heart in Bohemia. The first separate geographical map of the European continent was also published in the 1540 edition of Munster's Geographia. So Munster's two maps of Europe - the metaphorical iconographic Queen and the geographical Continent - point to two quite separate and divergent traditions of cartographic representation which in fact date back at least two centuries earlier. In the tradition of Munster's Queen, the World and its regions, were 
presented not as they appeared in the "reality" of contemporary cartographers, but as metaphors, their hidden deeper meanings conveyed through allegory and symbol and through the use of the imaginary and anthropomorphic. Indeed anthropomorphic cartography finds earliest expression in the remarkable work of the $14^{\text {th }}$ Century Pavian monk \& Papal scribe, Opicinus de Canistris [b.1296].

In Opicinus de Canistris's manuscript portolan chart of the Mediterranean c.1341, the coastlines of Southern Europe become the shape of a woman, whilst the features and form of her male suitor and companion follow the outline of the coasts of North Africa. There are many different strands and levels to this alternative tradition of map representation, unfortunately most of them beyond the scope of our consideration here. However in the $19^{\text {th }}$ Century a new and quite distinctive genre of European cartography emerged - the political cartoon map - which uniquely reflected and mirrored the momentous political and cultural changes that were transforming the landscape of Europe.

Figure 1. Sebastian Munster (after Johannes Bucius), Der Cosmography (Europe in the form of a Queen), Basel, Switzerland, c. 1588.

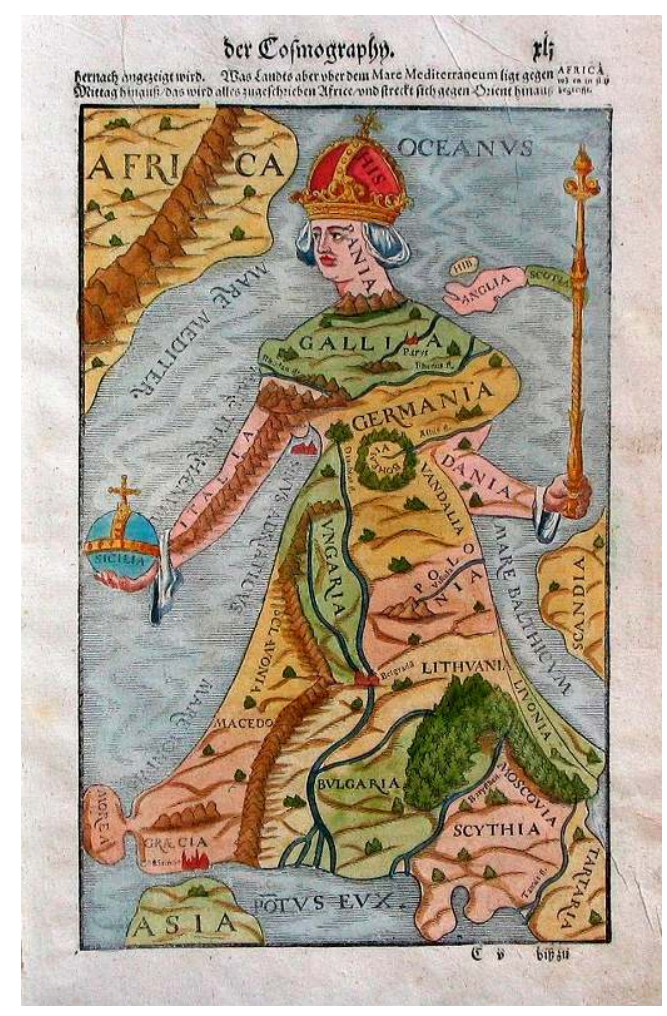

\section{Early $19^{\text {th }}$ Century Origins of the Political Cartoon Map of Europe}

The political broadside and satirical print had been a feature of European societies since the $16^{\text {th }}$ Century. One of the early prototypes for the $19^{\text {th }}$ Century political cartoon map can perhaps be recognised in Laurie \& Whittle's A Whimsical Map of Europe [London, England, 1806] in which the British Isles is a "sturdy old fellow, astride on a whale", a hybrid version of the three droll caricature maps of England, Scotland and Ireland, 
entitled Geography Bewitched, published by Bowles and Carver in about 1792. The Poetical description below the Whimsical Map of Europe considers the sturdy old fellow's singular position as the ruler of the waves and the preserver of liberty, looking on undefeated over Europe, each of its countries symbolically represented, a Continent ravaged by Napoleonic tyranny and war.

5 The $17^{\text {th }}$ Century Dutch carte- $a$-figures literally "marginalised" its peoples and leaders. By contrast, $19^{\text {th }}$ Century European satirical maps first brought people and leaders onto the map, like actors on a stage, and then absorbed them into the very map itself. Initially the satirical humour derives from the caricaturization of the map's principal actors. Subsequently the whole map itself becomes "caricaturized", as individual national actors now assumed the exact form and shape of the respective countries of Europe, comparable to the way in which Munster's Queen had assumed the form and shape of the whole Continent of Europe. And not only were the political leaders of Europe satirized but, increasingly, separate and distinctive European national identities were given new and symbolic visual expression.

\section{The Development of the Satirical Map of Europe} 1848-70

6 The political cartoon map of Europe developed and took definitive form in the period between 1848 and 1870, years punctuated by European revolution, war and political upheaval. It is no coincidence that many political cartoon maps were published at exactly the same time as momentous events - the 1848 Revolution, the 1859 FrancoAustrian War, the Crimean War [1853-56], and the Franco-Prussian War [1870-71]. Political upheaval, especially revolution and war, provided ready ammunition for contemporary satirists and inspiration to the cartoonists and artists with whom they worked.

7 Engraved by $\mathrm{F}$ Werner in Vienna, a lithograph map entitled Politische Karte von Oesterreich [Vienna, Austria 1848] (Figure 2), is one of the few recorded cartoon maps, indeed possibly the earliest of the genre, to depict the events of 1848, a year which witnessed popular uprising and revolution across much of mainland Europe. The map illustrates, in novel fashion, the way in which the forces of reaction and conservatism within the Austrian Empire - the Imperial Court, the political elite, the Church and priesthood and the Army symbolically retain the "reins of power", in the face of a powerful popular explosion for political change. These reins appear on the map as extended strands of a web of control emanating from a central group of army leaders, clerics and aristocrats, spreading outwards across the different political and ethnically diverse regions of the Empire into the hands of local conservative protagonists on the ground. One of the figures, shown in the top left of the map, standing in lonely exile in England, is that of the former Austrian Chancellor, Klemens von Metternich [1773-1859], here depicted still holding on to one of those symbolic reins of power, despite his dismissal from office, under considerable popular pressure, in March 1848. Von Metternich had been one of the founders of the original post-Napoleonic "Congress" system, the so-called Concert of Europe, whose influence had done so much to maintain the European political status quo in the first decades of the Century after the Congress of Vienna [1815]. 
Figure 2. F. Werner (engraver), Politische Karte von Oesterreich, Vienna, Austria, 1848.

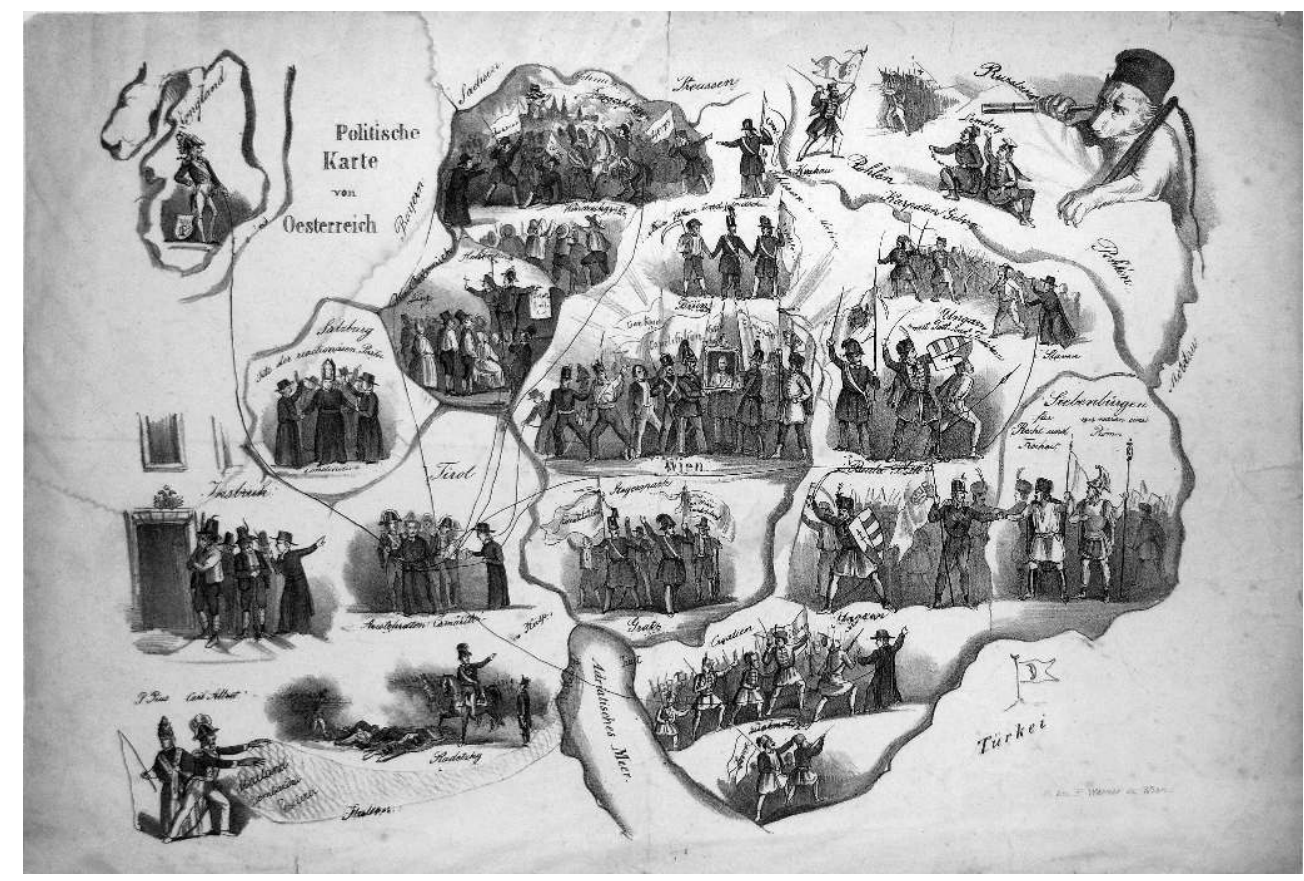

\section{Actors on the European Stage 1849-1859}

Ferdinand Schroeder's Rundgemaelde von Europa im August MDCCCCXLIX, from the Düsseldorfer Monateshefte, II Band [Verlag v. Arne \& Co, Düsseldorf, Germany, 1849] (Figure 3) and Emrik \& Binger's Dutch cartoon map Kaart van Europa 1859 [Haarlem, Netherlands, 1859], engraved by J. J. van Brederode, (Figure 4), reveal the manner in which the principal actors appeared simply as caricatures on the map. In the former, the giant figures of Louis-Napoleon of France and King Wilhelm IV of Prussia stand on a map of Northern Europe, brooms in hand, sweeping away the lilliputian detritus of the 1848 Revolution, whilst Queen Victoria looks on askance from across the English Channel. In the latter, the political and military giants, French Emperor Napoleon III and Austrian Emperor Franz Josef, bayoneted rifles in hand, face each other in armed conflict astride Northern Italy. 
Figure 3. F. Schroeder, Rundgemaelde von Europa im August MDCCCXLIX, Düsseldorf, Germany, 1849.

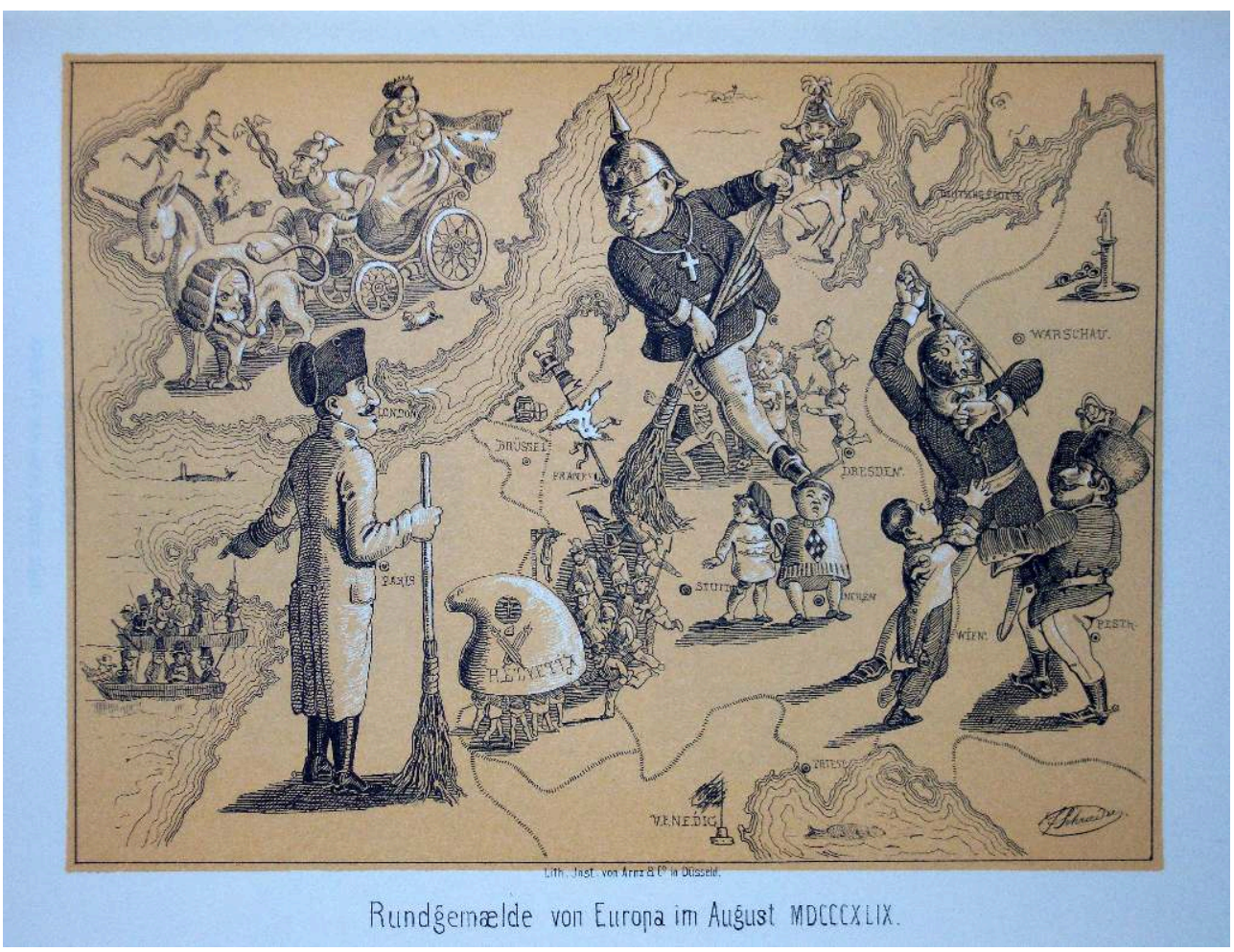

Figure 4. Emrik \& Binger, Kaart van Europa 1859, Haarlem, Netherlands, 1859.

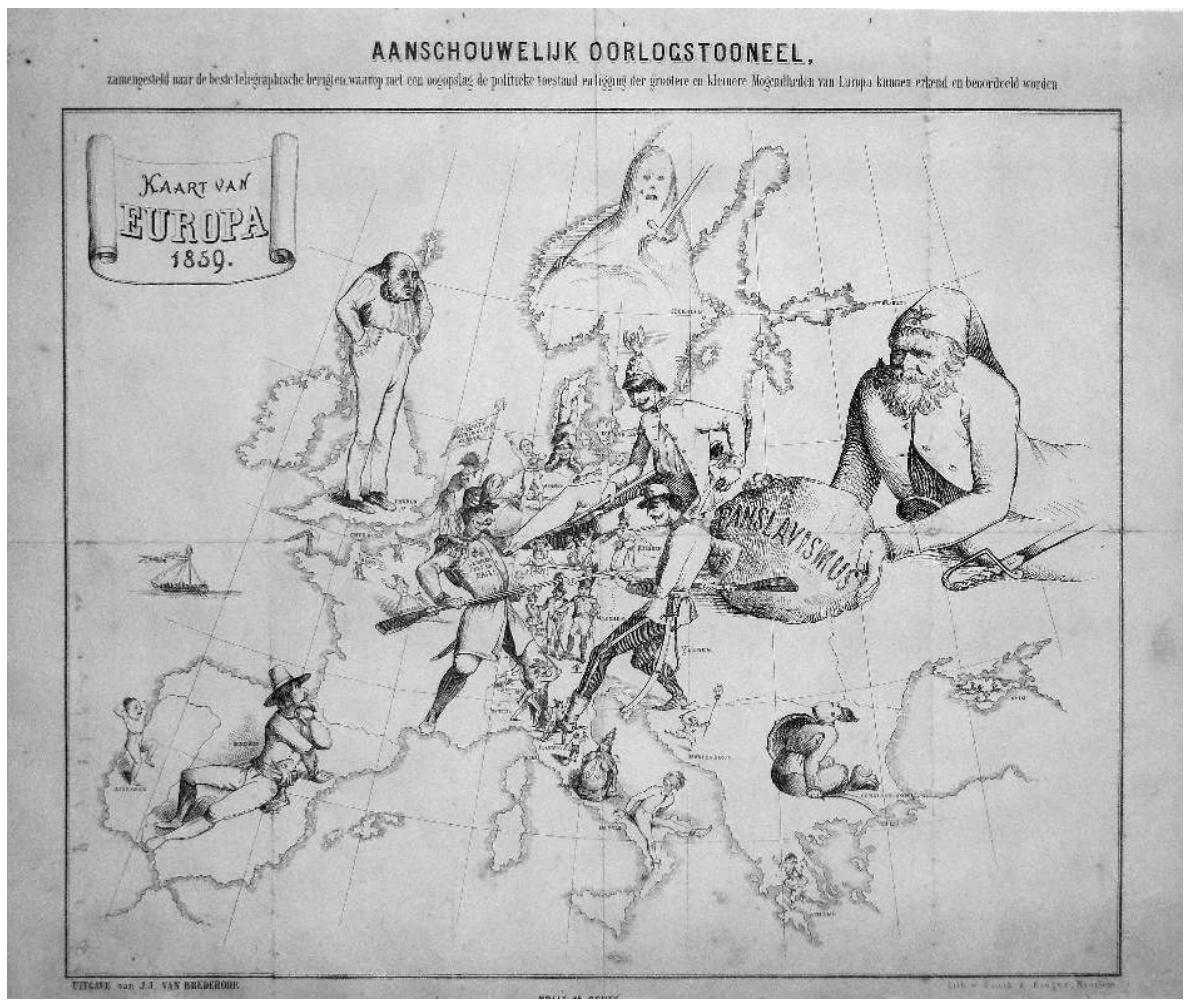




\section{Europe Caricaturized - 1854-1870}

9 In two further maps, Berendsohn's map of Europe at the time of Crimean War, Komische Karte des Kriegsschauplatzes [Verlag B S Berendsohn, Hamburg, Germany, 1854], (Figure 5), and Paul Hadol's map of 1870, Nouvelle Carte d'Europe dressée pour 1870 [Imprimerie Valée, Paris, France, 1870], (Figure 6), we finally see Europe fully "caricaturized", in both symbolic and anthropomorphic fashion. Paul Hadol [1835-1875] was one of the most acerbic satirical critics of the French Imperial regime, perhaps best known for the biting grotesque caricatures of La menagerie imperiale, composée des ruminants, amphibies, carnivores,et autres budgetivores qui ont devoré la France pendant 20 ans [Paris, France, 1871], in which 31 of the leading members of the Imperial family and Court and principal politicians of the defeated Second Empire were viciously satirised, their enlarged faces and distorted physiognomies placed on a variety of ridiculous and demeaning animal torsos.

Figure 5. G B Berendsohn, Komische Karte des Kriegsschauplatzes, Hamburg, Germany, 1854.

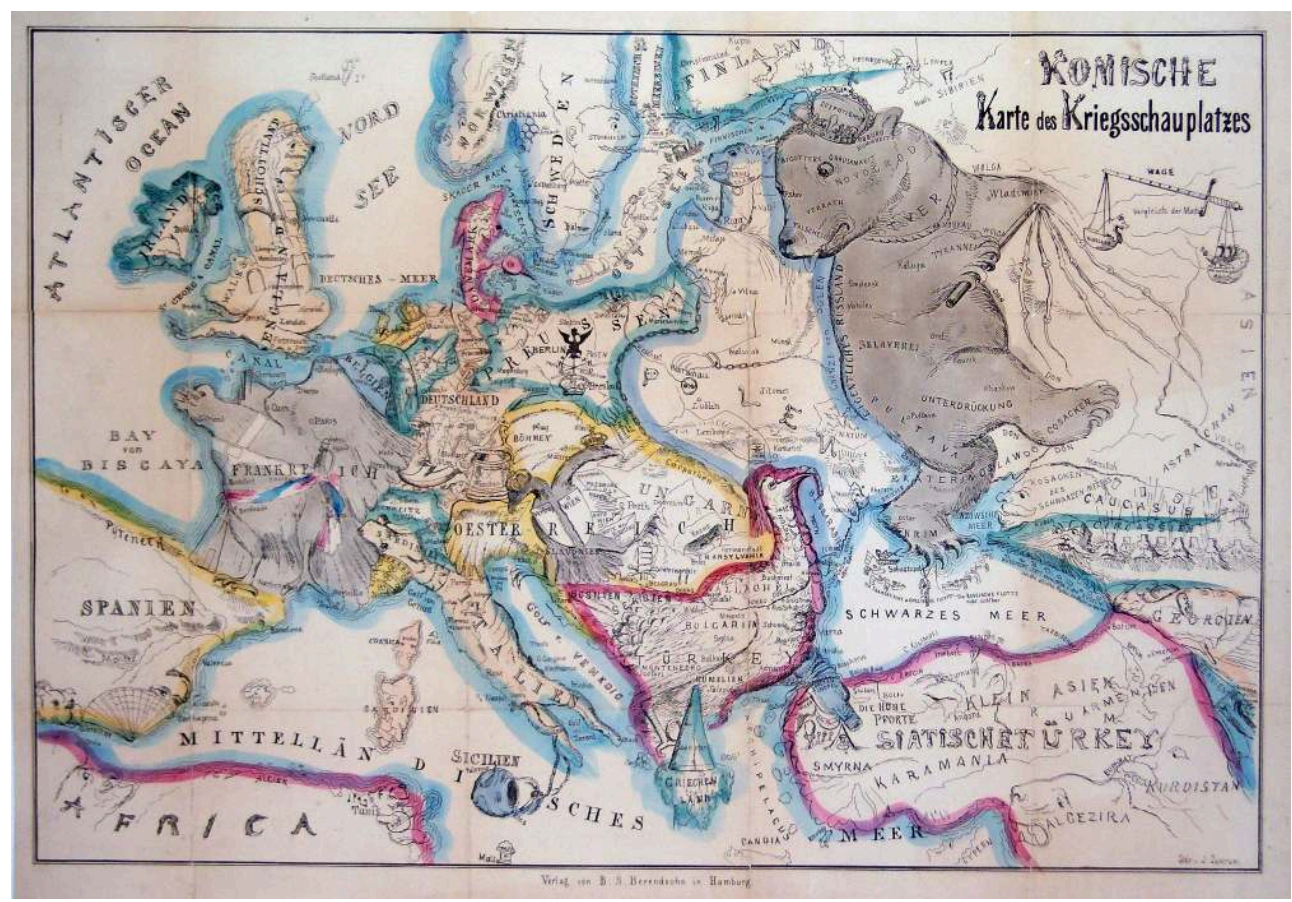




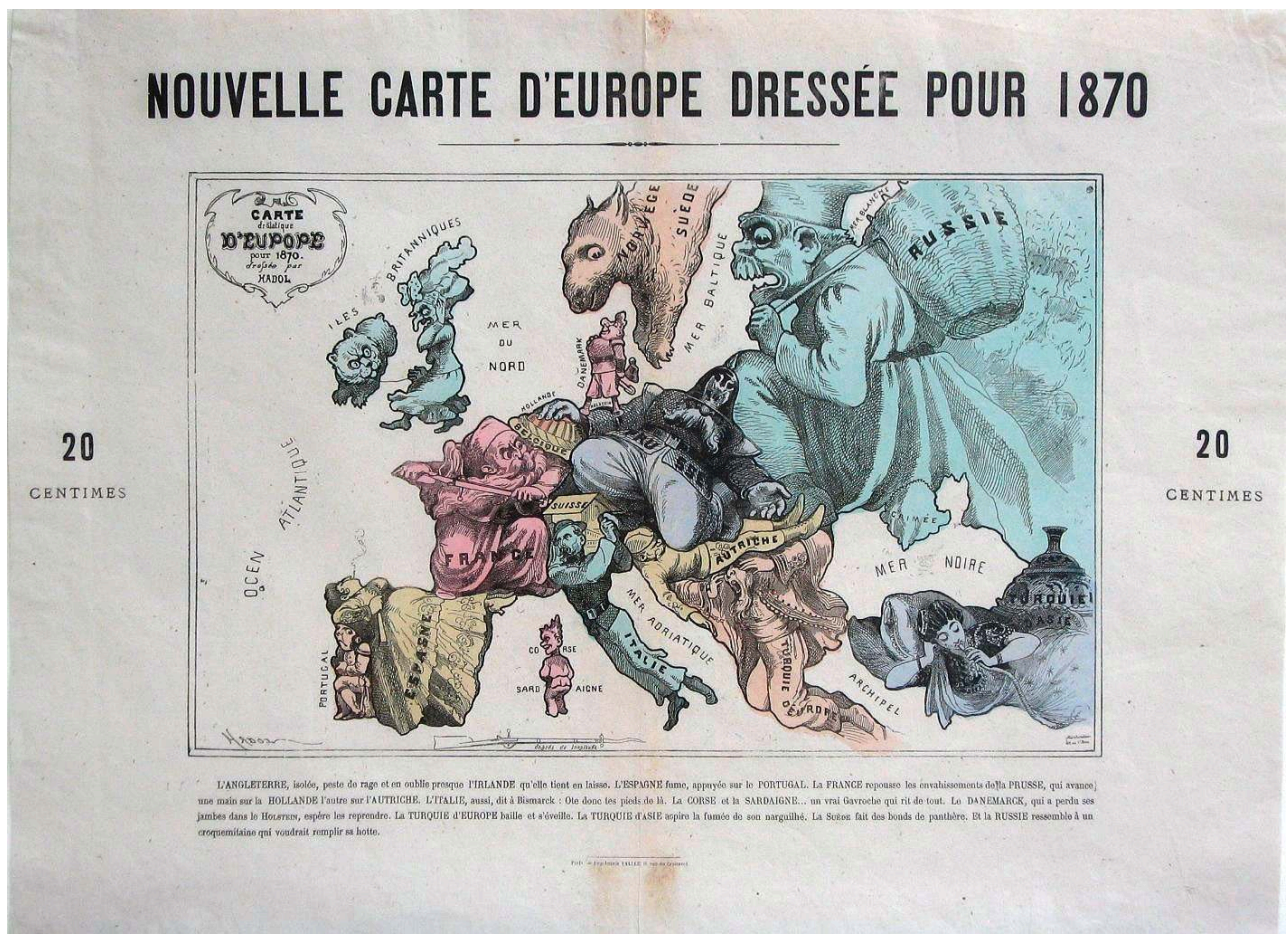

\section{The Era of the Satirical Magazine \& Caricature Artist}

This was an era which witnessed a massive upsurge in the popularity of illustrated satirical magazines across Europe - particularly in France, Germany and Britain. In France one of the most popular of the period was Le Charivari, first published in 1832, and in the subsequent period a forum for the inspirational master cartoonist, Honoré Daumier [1808-1879]. Paul Hadol's engraving from January 1867 entitled Carte de Visite $d u$ Charivari, includes portraits of all of the principal writers and artists of the Magazine, including prominent figures such as Daumier, Gill, Cham and Hadol himself. In this satirical milieu, the boundaries between the art of the cartoon and the art of cartography became increasingly blurred and it is no surprise that leading cartoonists such as André Gill [1840-1885], Paul Hadol [1835-1875], Albert Robida [1848-1926], and André Belloguet [1830-1873], were also amongst the foremost exponents of this new map genre.

The Carte du Théâtre de la Guerre des Journaux, (Figure 7), designed by André Gill, illustrates the front page of the satirical newspaper, La Lune on July $1^{\text {st }} 1866$, at the height of the Austro-Prussian War, and just two days before the defining Battle of Sadowa. A map which one expects to display the theatre of the Prussian war is wonderfully transformed into a cartoon map depicting the battle for circulation and readership between the leading French newspapers and magazines of the period. States and principalities of what appears to be a map of central Europe become the imaginary domains of contemporary French newspaper barons and magazine owners. A symbolic El Dorado, the Royaume de L'Abonné - the Kingdom of the subscriber - a land of peace and tranquility, secluded from the skirmishes and battles of the popular press, and filled with potential riches, appears in the lower right of the engraving. 
Figure 7. André Gill, Carte du Théâtre de la Guerre des Journaux, La Lune, July 1st 1866.

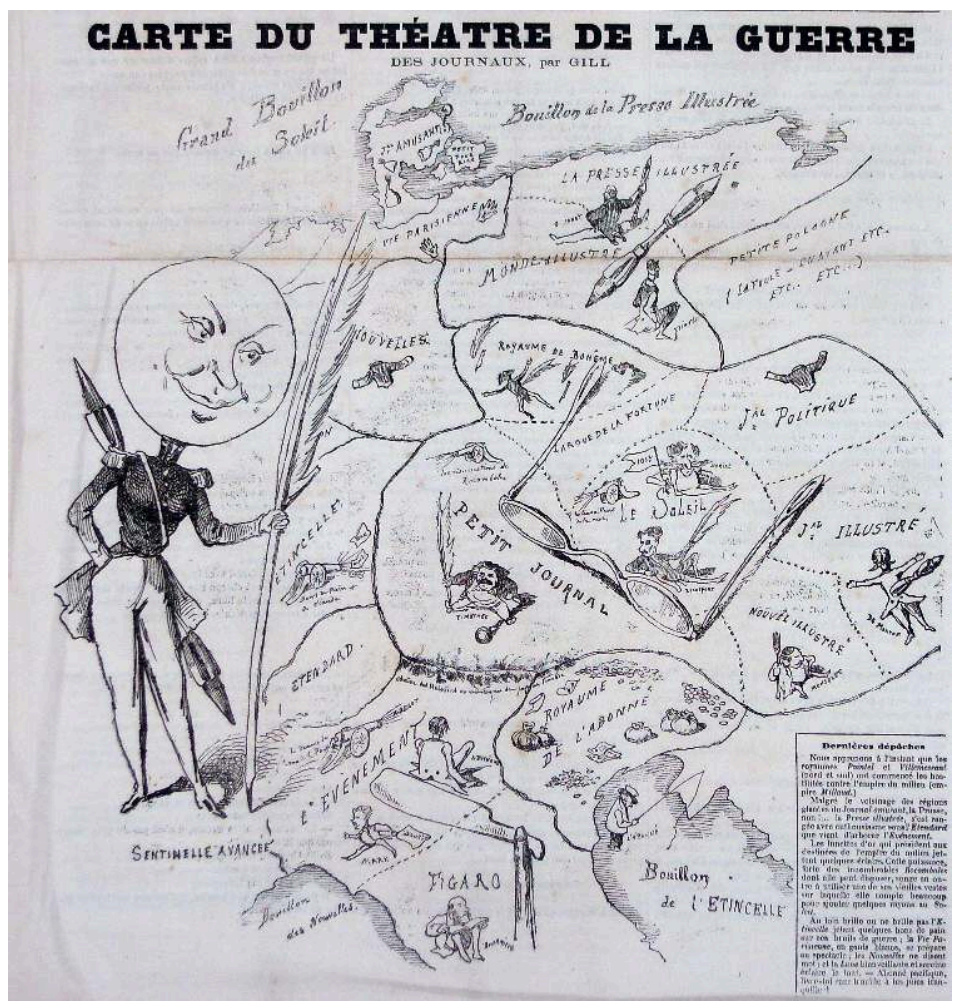

\section{Paul Hadol: Nouvelle Carte d'Europe dressée pour 1870}

Many of the political cartoon maps of this period were published as separate loose sheets available from print shops and street vendors - Paul Hadol's famous map of 1870, for example, was offered for sale for a price of 20 centimes - cheap and accessible to the population at large. The simple design and striking and amusing imagery also made such maps popular at all levels of society, from the least literate to the best educated. Indeed one of the most interesting features of these maps is their relative lack of definitive political allegiance, bias or propaganda. They were ostensibly "drolatique", "allegoric" or "serio-comic". Indeed Paul Hadol's map, first published in French, also appeared in English, Italian, Dutch, and German language editions without revision, perhaps indicating that such maps were also acquiring a popularity in their own right, beyond national boundaries and any ostensible political message that they might convey, simply as amusing, entertaining and easily affordable collectors' items.

\section{Fred W Rose \& the Serio-Comic Map tradition 1871-1914}

Unlike the preceding 25 years, the period between 1871 and 1914 was one of relative peace within the boundaries of Europe. The European political cartoon map genre was crystallized, formalized and refined, perhaps most strikingly through a series of so- 
called "Serio-Comic" Maps by the English map maker Fred W Rose. Very little is known of Rose himself, though a lithographic printer of this name is recorded working in central London in the late $19^{\text {th }}$ Century. His three best-known works are Serio-Comic War Map for the Year 1877 [G W Bacon \& Co, London, England, 1877], (Figure 8); Angling in Troubled Waters [G W Bacon \& Co, London, England, 1899] and John Bull and His Friends [G W Bacon \& Co, London, England, 1900]. Rose's maps highlight the fact that it was increasingly events outside Europe - in the Ottoman Empire in 1877-8 and later in the emergent colonial theatres of Africa and Asia- where underlying European political rivalries and power struggles were played out. Another interesting feature of Rose's maps is the manner in which the smaller nations of Eastern Europe are shown emerging as fledgling sovereign states, independent of the Ottoman Empire, in the period immediately after 1878 . The continuity and coherence of the European political cartoon map as an established and distinctive genre is perhaps best exemplified by the publication in November 1915 in the German Magazine Das Plakat of two such maps side by side: on the left a German edition of Paul Hadol's comic map of 1870, on the right a new revised and updated version designed by the well-known German artist, Walter Trier [1890-1951] entitled Karte von Europa im Jahre 1914.

Figure 8. Fred W Rose, Revised Edition. Serio-Comic War Map for the Year 1877, London, England, 1877.

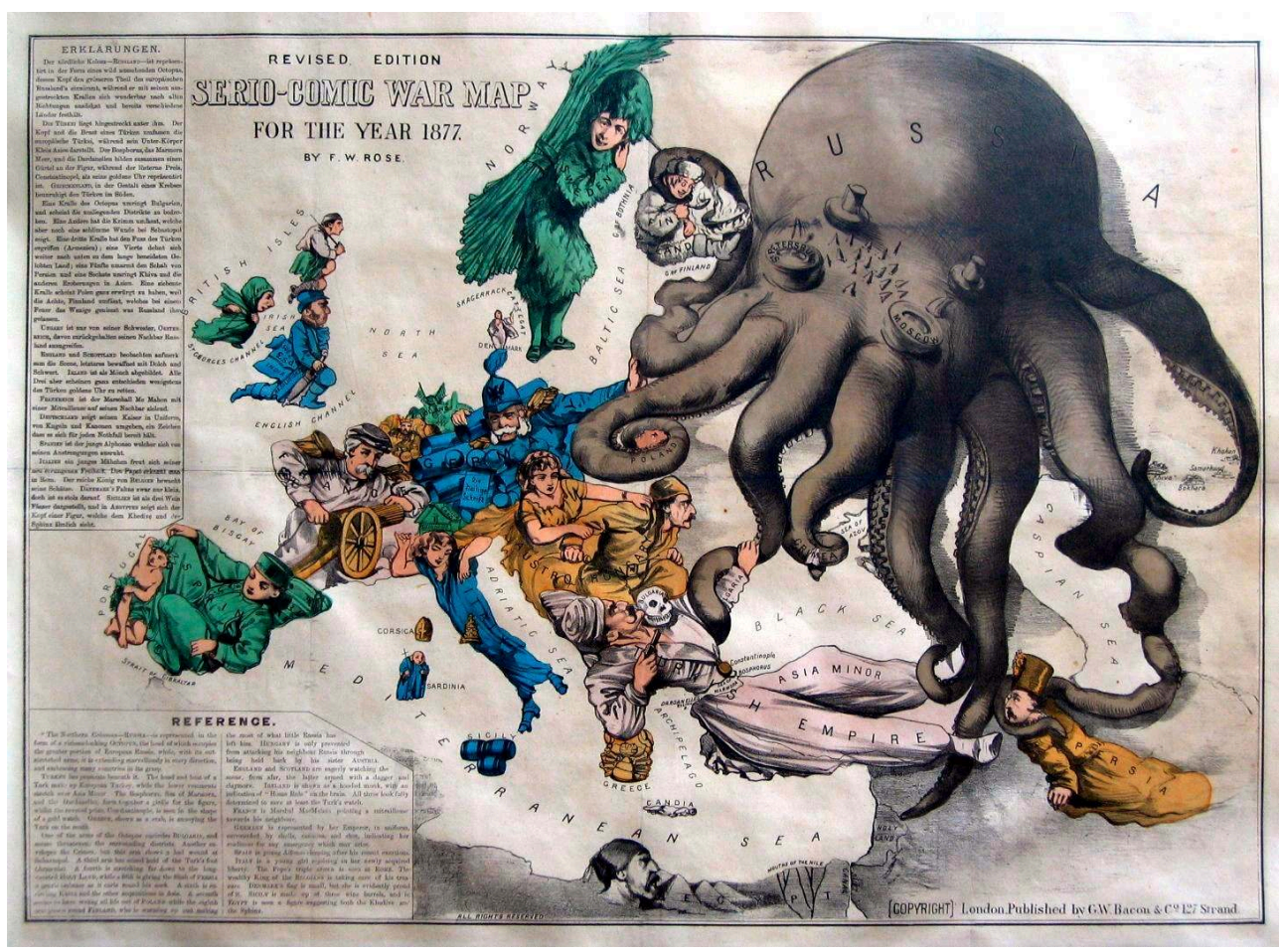

\section{The Political Cartoon Map \& Propaganda}

The advent of European-wide conflict in 1914, witnessed the transformation of the political cartoon map from medium of serio-comic satire into instrument of political propaganda. Indeed the political fall-out of the Treaty of Versailles [1919] and increasingly ideological, geo-political and global perspectives on European politics, meant that as a distinct and separate European-focused map genre it rapidly died a 
natural death. By now there were also new methods of mass media and communication - the cinema, the radio and the propaganda poster - through which satire and political propaganda could be disseminated more widely and effectively. Nonetheless the stylistic and visual legacy of the late $19^{\text {th }}$ and early $20^{\text {th }}$ Century European political cartoon map can still be recognised in these new media, not least in the political propaganda poster, through to the end of the Second World War.

\section{Cartoon Maps as Educational aids}

One of the most famous and innovative series of $19^{\text {th }}$ Century anthropomorphic maps is Geographical Fun being Humorous Outlines of Various Countries [Hodder \& Staughton, London, England, 1869]. The designs of this series of twelve maps encompassing England, Scotland, Wales and Ireland and nine of the principal countries of Europe, were the work of a talented young Englishwoman, Lilian Lancaster [1852-1939]. The journalist and London antiquary, William Harvey [1796-1873], who used the pseudonym Aleph, provided the lines of verse that accompany each map. In the book's introduction Harvey noted: "It is believed that these illustrations of Geography may be rendered educational and prove of service to young scholars, who commonly think Globes and Maps but wearisome aids to knowledge, by enabling them to retain the outline of various countries so humorously caricatured in the work, by associating them in their mind's eye with odd fancy figures." However Lancaster's designs and Aleph's commentaries are not without resonant national symbolism: England assumes the identity of Queen Victoria in the guise of Britannia ruling the waves; Russia the back-to-back figures of a great Bear and Tsar Alexander II. Italy assumes the form of the popular Italian patriot, Guiseppe Garibaldi, and Prussia the combined figures of a supplicant Kaiser, Wilhelm I presenting notes to his Iron Chancellor, Otto von Bismarck. Lilian Lancaster herself was a remarkable figure, subsequently becoming a popular Victorian actress, singer, comédienne and pantomime artiste. As an actress, she continued to make use of her earlier talents as a cartoonist and cartographer. Surviving contemporary newspaper reports suggest that one of her most popular routines as a comédienne was as a "lightning cartoonist", sitting very close to the front of the theatre stage and incorporating the faces of those in the front rows of her audience into cartoons and caricature map sketches that she would rapidly produce on the spot. A collection of her unique manuscript cartoon maps, many amusingly referencing late $19^{\text {th }}$ Century political and theatrical themes, is now in the British Library.

\section{Satirical Maps, Physiognomy \& Phrenology}

André Belloguet's L'Europe Comique, subtitled Cocasserie, dediée à la Jeunesse [Beer editeur, Lith. Jannin, Paris, France, 1867] (Figure 9) is an equally remarkable creation, an outlandish riot of different physiognomies and expressive faces whose shapes roughly follow the established political boundaries of contemporary Europe. Most dominant amongst them is the giant figure of Russia, a cultured and erudite gentleman sporting a wide-brimmed hat and wearing a monacle. This may perhaps symbolise Russia's growing cultural self-expression in the fields of literature, music and the arts.

Whether Belloguet's map had any deeper meanings beyond mere cocasserie (foolery) is not at all clear. Certainly it appears to lack any discernible political overtones and 
claims simply to "amuser et instruire" (amuse and instruct). The art of physiognomy sought to deduce hidden personal traits and characteristics from the visible features and expressions of an individual's face. The sister science of phrenology, equally popular in the $19^{\text {th }}$ Century, was the supposed method by which similar individual character and personality traits, even a propensity towards criminality, could be determined by expert examination of the shape and form of the head. Many scholars have previously noted these close affinities between symbolic cartography and phrenology and physiognomy. Indeed Belloguet's enduring fascination with the human face and with an individual's hidden character and personality traits as the basis for caricature and satire is vividly apparent in his subsequent work, Pilori-Phrénologie, a series of twelve political caricature portraits produced at the time of the FrancoPrussian War in 1871. In one, entitled Bismarckoff I, the figure of German Chancellor Otto von Bismarck is transformed into a vile malevolent grotesque, blood dripping from his moustache and mouth. Symbolic images of a Krupp cannon appear on his right cheek and a political spider's web of Europe on his forehead, on which Germany's closest neighbours - France, Austria, Denmark and Holland - are depicted as trapped \& dying flies.

\section{European National Stereotypes}

William Harvey had also noted that the maps displayed in Geographical Fun may "lead to the profitable curiosity of youthful students and embue the mind with a healthful taste for an acquaintance with foreign lands". Indeed, acquaintance and encounters with foreign lands had always been a source of great humour for the satirical printmaker. In the previous Century it had led to an outpouring of literature and prints which had formalised many national stereotypes, not least those of the French and English. So it was now, in the period of the emergent nation-state, that new representational national identities were born - not just human, but animal, historical and mythical. In L'Europe en 1876, à la Portée des Grands Esprits [H Demarc, Imprimerie Bernard, Paris, 1876], the European nations and their respective national traits, customs and characteristics are defined with biting satirical humour in descriptions around the periphery of the map. Europe for example is a Continent which produces "les nouveaux fusils, les guerres, les canons et autres engins d'amélioration" (new rifles, wars, cannons and other engines of improvement) and where Man is serviced by more civilised beasts, such as the cow and the sheep, who sacrifice themselves for the greater good in order to keep Man clothed and fed. Great Britain is a country where "la majorité de la population est composée de mylords, de filous et de policemens" and whose principal exports are pickpockets (the best in the World), silk taffeta and roast beef. As far as national customs are concerned, the British suffer badly from indigestion through eating an excess of plum pudding “... et [ont coutume] de venir de temps en temps en France jouer la comédie dans les anciens vaudevilles". G B Berendsohn's Komische Karte des Kriegsschauplatzes (qv) is the first map to lay down many now familiar national identities - the frightening great Russian Bear; the French Imperial Eagle (adopted as a symbol of France during the Second Empire (1852-1870)) and the courageous British Lion. On Paul Hadol's 1870 map, Russia appears as a giant "rag collector" and in later embodiments, for example on the Humoristische Karte von Europa im Jahre 1914 [K Lehamnn-Dumont, Sächs-Verlagsanstalt, Dresden, Germany 1914], as a wild ogre or a vodka-drinking peasant, surrounded by explosive powder kegs, symbolic of social and political instability. Germany frequently takes on the form of the 
pickelhauber-helmeted Prussian militarist or the age-old symbolic artisan figure, a man of sleepy rustic solidity - Der Deutsche Michel - invariably shown wearing his tasselled nightcap or Michelsmütze.

\section{John Bull \& Marianne}

19 In this period we also witness the re-emergence on European satirical maps of two important $18^{\text {th }}$ Century national icons - John Bull, the satirical representative of Great Britain, and Marianne, the symbolic Revolutionary heroine of France. John Bull had been the creation of Dr. John Arbuthnot in 1712 and by the late $18^{\text {th }}$ Century had become the cartoon image of portly, conservative, down-to-earth English country squire, frequently portrayed by the likes of Gillray, Cruickshank and Rowlandson, and frequently contrasted with the scrawny French sans-culotte or diminuitive Boney Bonaparte. Through the illustrations of John Leech and John Teniel in Punch Magazine in the mid- $19^{\text {th }}$ Century, John Bull's cartoon image was gradually refined becoming the stout man in tailcoat and breeches, often wearing a top hat, a waistcoat emblazoned with the Union flag of Great Britain and frequently accompanied by a ferocious bulldog. In France, the mythical figure of Marianne, the symbol of Revolution, wearer of the Phrygian cap of Liberty, dated back to early days of the French revolution. Pictured by Delacroix in his great painting Liberty leading the People, commemorating of the July Revolution of 1830, she was adopted as the symbol of France by the Second Republic in 1848. Banished as subversive under the Second Empire, she re-emerged in the mid 1870s, making one of her earliest subsequent cartographic appearances on L'Europe en 1876.

\section{The European Menagerie}

The late $19^{\text {th }}$ and early $20^{\text {th }}$ Century also saw many European national identities crossreferenced to the Animal Kingdom. The map, L'Europe Animale, Physiologie Comique [Bruxelles, Belgium, 1882] is a further work of the previously mentioned French satirical artist, André Belloguet, who had fled to Bruxelles after the Paris Commune and subsequently worked for the Belgian satirical magazine, Le Lutin. Belloguet identifies the countries of Europe with a menagerie of different animals, each reflecting their perceived national traits and characteristics. For example, the British Isles takes on the form of an observant Octopus ready to give electric shocks to the rest of Europe; France a wakeful cockerel; Germany a cunning fox resting amicably on its Austrian neighbour, a greedy and anxious Great Owl; and Russia a giant White Bear, eating a croissant (representing Turkey) and wearing around its neck the keys to the "Eastern Question". Belloguet's map clearly has deep political overtones but, like Harvey before, also claims to have an underlying educational purpose, noting that "Cette carte s'adresse à l'enfant autant que l'homme, car rien ne peut être plus puissant pour fixer et éclairer la mémoire qui tâlonne dans la dédale géographique".

In Hark! Hark! The Dogs do Bark! With Notes by Walter Emanuel [Johnson, Riddle \& Co, London, England, 1914], the map of Europe receives a canine make-over. The commentary by Walter Emanuel begins with the words, The Dogs of War are loose in Europe and a nice noise they are making! Walter Emmanuel [1869-1915], a long-time contributor to Punch Magazine, had also become more widely known as an author of a 
series of charming anthropomorphic dog books, illustrated by artist Cecil Aldin, many of which still remain immensely popular today. Included amongst these are A Dog Day [William Heinemann, London, England, 1902] and The Dogs of War (Wherein the heroworshipper portrays the hero and incidentally gives an account of the greatest dogs' club in the world) [Bradbury, Agnew \& Co, London, England, 1906]. In Emanuel's map, Germany is the Dachshund, "mated for better or worse" to an Austrian Mongrel. Belgium is a game little Griffon, France a large Poodle, "a smart dandified fellow" and Britain, the ever-watchful Bulldog, sleeping with one eye open, and with a ferocious bite and a habit of never letting go, in this case, of the Dachshund's nose.

A similar German map, Europäische Treibjagd [G Schiedermeier \& Co, Regensburg, Germany, c.1915] depicts the armies of Germany and Austria repulsing the combined assaults from East and West of a grosseuropäische Menagerie (great European menagerie) which include the British Bulldog, the Belgian Hare, the French Cockerel and Monkey, the Serbian Pig, the Russian Bear, and the Japanese Ape.

\section{From Satire to Propaganda}

With the advent of War, the map of Europe was no longer "serio-comic", it was now militarized and politicized, a source of propaganda that could determine the difference between Allied or German Victory and Defeat. Amongst all of the combatant Powers, it rapidly became a question of winning hearts and minds and mobilising a patriotic spirit and the animosity of the general community against the common Enemy. Britain witnessed the creation of the War Propaganda Bureau [1914] manned by many of the leading English authors of the day such as Rudyard Kipling, Thomas Hardy \& H G Wells. Later, wider-ranging, reincarnations appeared in the form of the Department of Information [1917] and Ministry of Information [1918]. The beginning of propagandist onslaught can be seen in a German poster of late 1914, Europäische Revue. Tötet den Adler! [Walter Nölting, Hamburg, Germany, 1914], a German version of John Henry Amschewitz's earlier English poster European Revue - Kill that Eagle [G W Bacon \& Co, London 1914], published shortly after the outbreak of war in August 1914. Nölting places considerable emphasis on the British slogan "Business as Usual" printed across the south of England. This slogan had in fact been coined by British businesses and shopkeepers as a patriotic expression of commercial resilience and continuity in a time of war. The phrase was then taken up by Winston Churchill, First Sea Lord to the Admiralty, who declared "The maxim of the British people is Business as usual". The German propagandist jumps upon this slogan as definitive proof of premeditated English treachery, completely justifying England's centuries-old soubriquet Perfidious Albion. The suggestion is that the War is just an extension of British business by other means, pursued and prosecuted mainly through Britain's allies and on allied territory for selfinterested, politically expansionist ends.

The anonymous German poster entitled L'Entente Cordiale [Germany, 1915] (Figure 10) demonstrates this propaganda shift even more poignantly. The title refers to the Anglo-French alliance originally signed in 1904. It perhaps makes a pun of the French words corde (rope or twine) and cordiale (heartfelt), as the image portrays a giant British spider voraciously consuming a symbolic French soldier and spreading her legs and weaving an all-encircling web across the whole of Western Europe and the Mediterranean. Onlookers, including Uncle Sam, are fully entwined in the spider's fine 
threads on the peripheries of the map. The Imperial German Eagle surveys the scene in the foreground, whilst German U-boats cut through the outermost strands of the web, a reference to the increasing impact of German submarine attacks on British shipping in 1915.

In the same way as German propaganda played on the expansionist aims of Great Britain, French propaganda highlighted the historic militarism of Prussia and Germany. Maurice Neumont's propaganda poster of 1917, uses a quotation from the French leader Mirabeau from 1788 to underscore the point that: La Guerre est l'Industrie Nationale de la Prusse. The poster graphically charts not only the growth in Prussia's armed forces over the previous century but also her territorial expansion across Western Europe. Prussia and Germany strikingly take on the shape and form of a giant octopus, whose tentacles spread menacingly across Western Europe and beyond.

In the immediate post-war settlement, as the map of Europe was redrawn at the Treaty of Versailles [1919], one of the principal issues to emerge was the problematic right of political self-determination for the smaller nations of Europe, as promulgated by Woodrow Wilson. In fact, contrary to popular belief, the origins of the term "selfdetermination" came not from the liberal ideals of the American President but from Bolshevik Russia in the wake of the 1917 Russian Revolution. Self-determination in this broader context implied not Wilson's original "Peace with the consent of the governed" but the ideal of an international peace involving colonial liberation and the end to the perceived cynical imperialism of the principal Allied Powers.

27 A fascinating German propaganda poster Was von der Entente übrig bliebe [F Klimesch, Berlin, Germany, c.1918], points to the blatant injustices of this situation in a global context and as viewed from the German perspective. It presents a map of the World dominated by the Entente or Allied Powers - Britain, France, Russia and America. Their colonial possessions are presented in the form of symbolic animals - the British Lion, the French Cockerel, the Russian Bear and the American Bison, each animal held by their respective colonial masters on a vast network of restraining reins, reminiscent of the 1848 map of Austria that we described earlier. The German banner states ironically: This is what would remain of the Entente powers if you seriously offered the "right of selfdetermination" to your own people and then let go of the reins!

\section{The Bolshevik propaganda poster}

Just as Bolshevik Russia berated the cynical imperialism of the Allied Powers at the end of World War I, as a new fledgling regime, through its own propaganda, and especially through the power of the poster, it attempted to redefine the new Bolshevik state and its potential enemies through a powerful and vibrant visual iconography. Amongst its foremost exponents was the great poster artist, Dmitri Moor [1883-1946]. Bolshevism quickly recognised the power of the poster as an instrument of mass media and propaganda. In the period of the Civil War [1918-21] staggeringly, over 11 million posters were published, "effectively turning a traditional art form into a political juggernaut". As Ruder highlights, the Russian revolutionary poster was heavily influenced by the traditions and heritage of Russian graphic art - by the lubok, an illustrated broadside which first appeared in the $17^{\text {th }}$ Century and by traditional Russian icon painting. Like the satirical artists of the $19^{\text {th }}$ Century, the art of caricature and satirical writing had blossomed in Russia in the wake of the abortive 1905 
Revolution, a milieu in which Moor had first learnt his craft as a caricature artist. Bolshevism quickly created a pantheon of iconographic national heroes, foremost amongst these the Russian worker, often depicted as a blacksmith at his forge, and the Red Army guard. An equally formalised Bolshevik demonology of state enemies - both at home and abroad - also emerges on posters of this period. In Dmitri Moor's Be On Your Guard! [Moscow, Russia, 1921], the giant figure of a Red Guard, almost blending and merging into the shape and form of the Russian map on which he stands, defends the country's Western borders against an assortment of Polish military adventurers, White Russian imperialists and European capitalist invaders, crushing many of them under his giant boots.

\section{World War II}

In the same way, during World War II, both Britain and Nazi Germany employed propaganda posters as instruments of mass media and through them we actually witness a reprise of many the earlier designs and models of caricaturization derived from the symbolic heritage of earlier political cartoon maps. In Spyk's Confiance - ses amputations se poursuivent méthodiquement [Paris, France, c.1942], a propaganda poster published in German occupied France, the figure of Winston Churchill is strikingly caricaturized as a giant octopus, cigar gripped between ruby-red lips, tentacles spreading out from Britain across a stylised map of Europe, Africa and the Middle East. Many of the limbs are cut and bleeding profusely. The names of Mers El-Kebir, Dakar, Libya-Egypt, Somalia, Syria, Germany and Norway, adjacent to these cuts and amputations, triumphantly declare recent British naval and military set-backs and defeats.

Seemingly almost a direct counter-blow to this, is the splendid French language propaganda poster by the satirical artist Kem (Kimon Evan Marengo) [1907-1988]: Une a une, on lui brisera les pattes [London, England, c.1943-44] clearly targeted at Occupied France and issued in late 1943 or early 1944. Here the figure of Adolf Hitler is presented as a Nazi spider, his legs spread across a map of Europe and North Africa. Allied aircraft, tanks and ships are depicted encircling him and one by one cutting through and breaking off his straggling limbs.

\section{Conclusions}

31 In 1935, the critic and philosopher, Walter Benjamin [1892-1940] writing in The Work of Art in the Age of Mechanical Reproduction, noted the increasing de-coupling of Art from what he considered to be its previously parasitical dependence on historic tradition and ritual, noting that "instead of being based on ritual, it (art) begins to be based on another practice - politics.". So we note that the most enduring and resonant image in satirical maps and posters throughout this period between 1845 and 1945 is not any specific symbol found embedded in ancient European ritual, High Art or classical culture. It is in fact one of the most sinister and menacing images of the actuality of politics and power - that of the all-entangling octopus and the spider weaving its web. The Swiss psychoanalyst Carl Jung [1875-1961] actually considered the spider's web as neither menacing nor sinister but rather as a symbol of wholeness, what he called a mandala, representing transformation, harmony and integration. Jung asserted that its symbolic wholeness 
derived from its circular formation, its ordered construction \& unique pattern of interlinked connections, and its underlying creative complexity. Perhaps Jung's spider's web mandala is in fact a fitting modern metaphor for the new supranational European political ideal of the late $20^{\text {th }}$ Century. Otto von Bismarck stated that "Anyone who speaks of Europe is wrong, it is a geographical expression". Present-day Europe is clearly much more than Von Bismarck's simple "geographical expression". It has, what is described in the European Commission's oft-repeated dictum, a "unity in diversity", a cultural diversity and unique symbolic iconography and heritage that so vibrantly comes to life in the satirical map of Europe between 1845 and 1945. In relation to the vision of a new supranational European unity and identity, as first proposed 50 years ago in the signing of the Treaty of Rome in 1957, Otto von Habsburg noted that Europe derived its strength and force from the richness of its autonomous cultures and languages and that a political formation needed to be found that would hold that diversity together whilst simultaneously preserving the rich hues of autonomous cultural colour. Perhaps it is no coincidence that the Treaty of Rome was signed in March 1957, precisely 420 years after the design of Johannes Bucius' earlier metaphorical map of the European Queen, an image of Renaissance Europe, equally rich in its wide-ranging hues of colour and with an equally powerful and unifying resonance and symbolism, not least to Otto van Habsburg's own $16^{\text {th }}$ Century Imperial ancestors.

\section{NOTES}

1. Quotation from: RUDER A. (2003), Art and the Shaping of Society: Russian Posters and Constructivism 1917-24 [Senior History Thesis, Bryn Mawr College, Bryn Mawr, Pennsylvania, USA] see: http:// triceratops. brynmawr.edu/dspace/bitstream/10066/671/1/2003RuderA.pdf

2. BENJAMIN Walter (1968), "The Work of Art in the Age of Mechanical Reproduction (1935)", Illuminations, New York Shocken Books, p. 224. Quoted in: RUDER A. (2003), Art \& the Shaping of Society: Russian Posters and Constructivism 1917-24, p.9.

\section{ABSTRACTS}

The map of Europe in the shape of a Queen originally designed by Johannes Putsch (Bucius) in 1537 and later published in Sebastian Munster's Cosmographia forms an interesting counterpoint to the first separate Continental map of the Europe [1540] from Munster's companion work, Geographia. These two European maps point to two quite distinct traditions of cartographic representation dating back to the early $14^{\text {th }}$ Century.

In the $19^{\text {th }}$ Century the metaphorical tradition of the European Queen witnessed a new and distinctive reincarnation - the political cartoon map of Europe - which reflected and mirrored 
the momentous political and cultural changes that transformed Europe between 1845 and 1945 . Individual nations were caricaturized and distinctive national identities given new and popular symbolic expression. Increasingly politicised, the cartoon map of Europe finally disappeared in the turmoil of World War I, victim to new and more powerful forms of mass media and communication. Its vestiges remain clearly visible in the design and iconography of subsequent propaganda posters of Bolshevik Russia and of World War II.

La carte de l'Europe sous les traits d'une reine, dessinée par Johannes Putsch (Bucius) en 1537 et publiée plus tard dans "Cosmographia" de Sebastian Munster, forme un contrepoint intéressant à la première carte continentale de l'Europe (1540) provenant de l'oeuvre de Munster Geographia. Ces deux cartes d'Europe renvoient à deux traditions distinctes de représentations cartographiques remontant au début du XIV ${ }^{\mathrm{e}}$ siècle.

$\mathrm{Au} \mathrm{XIX}^{\mathrm{e}}$ siècle, la tradition métaphorique de la Reine européenne fut le témoin d'une nouvelle réincarnation caractéristique - la carte politique de l'Europe en dessins humoristiques - qui reflétait les changements politiques et culturels majeurs ayant transformé l'Europe entre 1845 et 1945. Les nations y étaient caricaturées, et les identités nationales se voyaient attribuer une expression populaire symbolique. De plus en plus politisée, la carte de l'Europe en bande dessinée a finalement disparu dans la confusion de la Première Guerre mondiale, victime de nouvelles formes de médias, plus puissantes. Ses vestiges restent clairement visibles dans le design et l'iconographie des affiches de propagande ultérieures de la Russie bolchevique et de la Deuxième Guerre mondiale.

\section{INDEX}

Keywords: allegorical map, anthropomorphic map, political cartoon map, satirical map, seriocomic map, symbolic map, caricature, iconography, propaganda, national stereotype, John Bull, Deutsche Michel, Marianne

Mots-clés: carte allégorique, carte anthropomorphique, carte politique en bande dessinée, carte satirique, carte sério-comique, carte symbolique, caricature, iconographie, propagande, stéréotype national, John Bull, Deutsche Michel, Marianne

\section{AUTHOR}

\section{RODERICK M. BARRON}

P.O.Box 67, Sevenoaks, Kent TN13 3WW, England, rod@barron.co.uk 